\title{
THE ISSUE OF LEARNING AND TEACHING A FOREIGN LANGUAGE
}

\author{
Charkazova Sevda, Azerbaijan state university of oil and industry, Azerbaijan \\ DOI: https://doi.org/10.31435/rsglobal_conf/25032021/7462
}

\begin{abstract}
The article deals with the issue of teaching a foreign language in connection with the need to form students of certain competencies that allow them to participate in a new society based on knowledge. A complex of problems associated with teaching and learning a second foreign language is discussed, and ways to solve them are proposed.
\end{abstract}

Keywords: education; foreign language; the English language; principle of variability; intercultural communication; communication.

Educated people are needed for modern society. Education, which includes upbringing and training, is aimed at ensuring that in the modern world the objectively established conditions for the existence of a particular individual meet the needs of the entire society. This applies to the essential aspects of the life and activities of a particular person, primarily his cognitive activity and speech communication. In this regard, in recent years, the communicative-speech functions of teaching have come to the fore in Azerbaijani education, and, consequently, the subjects of the language cycle.

And what is actually a foreign language at school? Imagine a large class that consists of completely differently motivated children, with different learning rates and different ways of perceiving it. Even simpler objects in such conditions often turn into something obscure and hard to master. And what can we say about foreign languages, for better mastering which requires constant language practice. And, learning a foreign language, at best, they will give you a five-minute recording to listen to, and in the language that was used a hundred years ago. And there is no need to say that "we teach children the classical version of the language." This is, in fact, a dead stock of knowledge, with which in real life we will not go far. Why do we need knowledge of a foreign language? Communication when traveling abroad, reading original literature - these are, perhaps, the main reasons. But today's spoken language, including English, is constantly evolving. And almost all teachers hardly keep up with these innovations. And today's students, like fifty years ago, can say their names, how old they are. So, the same thing can be learned at home with any simple course in a couple of hours. And why then study a foreign language at school if you can easily master it at home? Even if we talk about vocabulary, then either it should be really large in order to be easy to read, or minimal in order to simply copy any text into a translator program and get acquainted with a good translation. The first option requires constant practice, and not a primitive translation of no less primitive texts that abound in little-used ones, in fact, but in the new textbooks there are many pictures, which, apparently, is intended to draw the attention of students to the study of the subject. Probably for the same purpose, posters with photographs are hung in many classrooms. And at school, in general, then it will already be based on the recognition of pictures. The best that the school could do is to provide at least weekly communication between students and a live native speaker.

The rapid development of society requires a person to be able to quickly adapt to dramatically changing conditions of existence. That is why creative activity becomes a necessary condition for scientific and technological progress, which requires a rethinking of the educational process and the presentation of new requirements for the content and development of education, which, in terms of foreign language proficiency, imply the ability not only to understand written and oral speech, but also the ability to act effectively in conditions foreign language communication, which implies a higher level of language and speech training.

Today, in Azerbaijani education, a key place is given to the principle of variability, which allows the teacher, on the one hand, to independently choose and design the pedagogical process, being within the framework of a certain educational standard, on the other hand, the student is given the opportunity to choose and participate in the development of academic disciplines, being included in the curriculum of the corresponding educational institution. This allows you to pay sufficient attention to the student as a developing personality - his ability to think independently, develop intellectually, and creatively solve assigned tasks. 
Currently, the problem of teaching a foreign language at school is extremely urgent. The teacher is faced with a difficult task to form certain competencies in the student that allow him to participate in intercultural communication. To do this, it is necessary to develop, improve, optimize, introduce new techniques and methods of teaching foreign languages, use all kinds of teaching aids in the classroom, strictly plan the educational process, constantly study the level of students' motivation, find new forms of interaction between the teacher and the student. In addition, teaching foreign languages at school should pursue the expansion and systematization of knowledge, abilities, skills related to foreign language communication, an increase in the lexical stock used, as well as further development of a foreign language speech culture.

One of the main widely studied foreign language in Azerbaijan is English. Teaching and learning a second foreign language is absolutely necessary for the following reasons:

1) The choice of a student to study several foreign languages from those included in the educational standard and curriculum will allow observing the key principle of Azerbaijani education the principle of variability, which will allow maintaining a balance of teacher-student interaction;

2) Independence of thinking, intellectuality of development, creative solution of the tasks set as components of the formation of the student's personality will become inevitable companions of the study of a second foreign language;

3) Personal growth, self-education, the need for advanced training in the relevant educational institutions of foreign countries will be an integral part of teaching a second foreign language;

4) Competencies that allow the student to participate in intercultural communication will become easily formed and achievable, their number will be optimized and minimized;

5) Knowledge, skills and abilities associated with foreign language communication will be systematized and expanded taking into account the educational standards of foreign countries;

6) The lexical stock and lexicological horizon used will be increased with the further development of a foreign language speech culture both within the framework of the existing educational standards of our state and within the educational systems of foreign countries;

7) Practical abilities and skills acquired in the study of a second foreign language will certainly allow to participate "in a new society based on knowledge", to actively develop in it, contributing to the expansion of foreign language communication and interpersonal communication.

First of all, it is necessary to improve the material and technical base of teaching a second foreign language in order to introduce modern techniques and methods of teaching foreign languages. Then edit curricula and curriculum, increasing the volume of credits of labor intensity, in no case wasting hours of other philological disciplines. It seems necessary to plan the educational process in such a way that the load on the teacher is not excessively increased, but is comfortable with the appropriate level of teacher remuneration, which should be as close as possible to the level of remuneration of the administration of the relevant institutions. And, finally, to "motivate" students of a second foreign language in the case of successful mastering of academic disciplines with long-term educational, introductory and educationalproduction practices in the countries that are native speakers of the foreign language being studied, where teachers of the second foreign language will take regular advanced training.

Teaching foreign languages in the era of globalization has its own characteristics and difficulties. Preparation for real intercultural communication determines the main goal of teaching foreign languages. It is possible to achieve this goal by means of the "Foreign language" subject. Today, approaches to teaching a foreign language are organized around its culturological component, and the idea of studying the culture of the people through language teaching becomes the main educational paradigm.

A foreign language lesson is a crossroads of cultures, it is a fact of presentation of a foreign language culture, it is a practice of intercultural communication, because every foreign word reflects a foreign world and a foreign culture. One of the components of the goal of teaching foreign languages is sociocultural competence, the formation of which directly depends on the formation of linguistic and speech competencies. When we study a language, we study the culture of native speakers.

Students who experience difficulties in mastering certain rules do not show interest in learning English, feel their insecurity and inability to this type of activity. Today, a completely new methodology of studying foreign languages is being formed, the purpose of which is to form communicative competence - to teach to communicate, speak, understand and respect another culture. The English language should not be perceived by students as an academic discipline, a subject, but should take a higher position - as an integral part of modern life, as a means of communication. 
Another of the problems typical for the process of teaching English and culture is the lack of assimilation of the proposed educational material. In this issue, in addition to motivating students, the relevance and attractiveness of the proposed training materials, as well as the professional and business competence of the teacher, play an important role. Many years of experience show that success in teaching comes when the teacher's educational practice contains elements of novelty, creative search, originality, high skill allows you to penetrate into the inner world of a student, see his aspirations and experiences.

Of course, in addition to the problems we have indicated, there are a number of others, which suggests that the system of teaching foreign languages requires serious revision, contributing to the destruction of old stereotypes of passive learning, forcing students to think, to seek answers to complex life questions together with the teacher. Understanding the advantages and disadvantages of the curriculum will allow you to adjust the course of learning a second foreign language and make it most effective.

We believe that teaching a second foreign language and its study will allow, in the shortest possible time, to achieve high results in increasing the demand for graduates of relevant educational institutions, their sustainable multilingual communication. It remains only to wait for the recognition of oneself as a part of the world community and certain socio-economic conditions for the development of the state. In this case, compulsory teaching of a second foreign language will become a reasonable continuation of the integration of the individual into the world space.

\section{REFERENCES}

1. Averina M.N. Analysis of the problems of teaching English in secondary schools. 2003. - No. 2. P. 110-119.

2. Ivanova O.V., Akhmetshina Y. I. The use of interactive teaching aids in the development of language competence at an English lesson at school // Philological sciences. No. 8. - P. 178-181.

3. Ivanova N.K., Mileeva M.N. Discourses on the Problems of Teaching a Foreign Language // Higher Education. No. 2. - 2014. - P. 89-95.

4. Ivanova N.K. Modern interactive tools in the process of teaching a foreign language at school // Scientific works of the Moscow University for the Humanities. - 2018. - No. 4. - P. 99-105.

5. Ilyina E.A. Development of writing skills of high school students in English lessons // Bulletin of the Tambov State University named after V.I. G.R. Derzhavin. - 2013. - No. 11. - P. 1-4. 